\title{
Role Impact in Knowledge Management of Automotive Component Firms in Indonesia
}

\author{
Anita Silvianita* \\ Business Administration Department \\ Telkom University \\ Bandung, Indonesia \\ anitasilivianita@telkomuniversity.ac.id
}

\author{
Tan Cheng Ling \\ Graduate School of Business \\ Universiti Sains Malaysia \\ Penang, Malaysia \\ tanchengling@usm.my
}

\begin{abstract}
The automotive industry in Indonesia has grown significantly as indicated by the increasing number of automotive sales from year to year. This growth has certainly an impact on the development of the automotive component firms in the country. In addition to serving domestic needs, this industry is also prepared to meet overseas demand, especially the ASEAN market, although Thailand is still the leader of the automotive component industry in the region. Among the resources needed, knowledge management (KM) is now considered as the most important resource. Therefore, the aim of this study is to find ways in which the industry can utilize KM Enabler factors in $\mathrm{KM}$ process as one of the main resources for work processes to improve company's performance in the future. This study uses questionnaire data collected from 85 managers representing different firms. Through multiple linear regression as the statistical tool, it was found that information technology is the most important factor in KM process of automotive component firms in Indonesia, followed by transformational leadership, human capital, and centralized organizational structure. This result is compatible with previous research, in which information technology was found to be needed in the knowledge management process. Therefore, automotive component firms in Indonesia are recommended to prioritize improving their information technology in the future.
\end{abstract}

Keywords: knowledge management enabler, knowledge management process, automotive component firms

\section{INTRODUCTION}

The rapid growth of automotive sales in Indonesia has opened up opportunities for the automotive component firms to develop. It is supported by government policy that requires each automotive product to use up to $90 \%$ of local components [1]. There are three layers or tiers in the automotive component firms. Tier 1 are component firms that supply Original Equipment Manufacturers (OEMs), their products are dominated by original brands or certain automotive industries, not to be sold freely to the market [2]. Firms in tier 1 are usually the joint ventures between local and foreign companies. Meanwhile, firms in tier 2 and 3 , in general, are the producers or suppliers for tier 1 firms, and their products are sold freely in the market.
Therefore, firms in tier 2 and 3 must tightly compete for sale their products in the market. In ASEAN, Indonesia has the largest automotive market share of $33.55 \%$, followed by Thailand with $24.29 \%$, Malaysia with $18.33 \%$, the Philippines with $11.36 \%$, Vietnam with $8.56 \%$, Singapore with $3.49 \%$, and Brunei Darussalam with $0.42 \%{ }^{2}$. However, in terms of the number of automotive component industries, Indonesia is still positioned below Thailand. Nevertheless, Thailand has also imported $5.6 \%$ of the total Indonesian automotive component production [3]

Despite having the opportunity to develop the automotive component industry, Indonesia still has some shortcomings compared to other producers in ASEAN. Indonesia is still below Thailand in terms of quality, R\&D, localization productivity, investment environment, and total evaluation. Malaysia is better than Indonesia in terms of $\mathrm{R} \& \mathrm{D}$ and localization [3]. In addition, the automotive component firms in Indonesia is still dominated by foreign companies and joint ventures, mostly Japanese.

To compete in ASEAN, Indonesian local firms must prioritize the improvement of their strategic capabilities in creating, developing, and maintaining competitive advantage [4]. In today's era of modern organizations, knowledge is considered as the main resource and even more important than human resources and corporate capital. Indonesia has a sufficient and potential resource to develop the automotive component industry. However, Indonesia is still behind other countries in automotive component industry. Therefore, to be compete, Indonesia's automotive component firms should concern with Knowledge Management (KM) as the main organizational strategy in creating new business processes to achieve superior organizational performance [5]. In business processes, firms can specifically implement what is called the KM Process. Based on [6], the KM Process is an activity initialized and / or maintained in an organization to enable management of the entire organizational knowledge assets, such as knowledge acquisition, knowledge creation, knowledge storage, and knowledge application.

To allow KM process run well throughout the work process, firms need to pay attention to the factors that trigger KM or referred to as KM Enablers. KM Enablers is a mechanism needed to encourage the creation of knowledge to then be shared and protected in a company. This study intends to determine the infrastructure readiness associated with KM enablers in the automotive component 
firms in Indonesia. Finally, this research aims to find ways in which the industry can utilize these triggering factors in their knowledge process as one of the main resources for work processes to improve company performance in the future.

\section{MATERIALS AND METHODS}

\section{A. Knowledge Management Process}

KM Process can be described as the process of capturing, storing, sharing, and using knowledge, or it can also be defined as tacit and explicit knowledge systematically organized from employees to be used by other employees for more effective and productive performance [7]. Therefore, the KM process is related to the practice of human resource management because it can influence the process of increasing knowledge into knowledge resources through the acquisition, creation, sharing, and utilization of knowledge [8]. From previous research, it is known that many factors can affect the KM Process. However, this study uses factors that are commonly used in previous studies, namely knowledge acquisition, knowledge creation, knowledge storage, and knowledge applications.

Knowledge acquisition is related to the activities of searching, identifying, selecting, collecting, organizing, and mapping information or knowledge from both inside and outside the company [9]. It is also supported by [10] stating that to achieve the important objectives of overall competitive performance, a company needs to maintain a constant acquisition of knowledge through competitors, customers and suppliers, or from internal and external business environments.

Knowledge creation is the capacity of an organization to produce knowledge and disseminate it within the organization, products, services, and systems of the organization. Therefore, knowledge creation should be a central point of a company's organizational strategy. Knowledge creation among members of an organization requires the ability to generate new knowledge and explore potential new skills and develop new ideas, programs, and processes to replace existing knowledge with new knowledge [11]. So, it is known from previous research that knowledge creation is often associated with innovation that refers to the successful application of new knowledge [12].

Knowledge storage is an activity to compile and organize knowledge for easier access and distribution among members in an organization. There are several activities in organizations related to the storage of knowledge, such as identification of good work practices, things to learn, organizational procedures and rules, absorption of each individual, development of organizational culture that represents values and beliefs companies, the use of information technology as a means of absorbing knowledge, and training [13].
Knowledge application is an activity that refers to the actualization of the use of knowledge to adjust strategic direction, solve problems, develop efficiency, and reduce costs. Every member of the organization can learn and produce new knowledge, meaning that the organization must be active to manage that knowledge [7]. Characteristics of processes that have combined knowledge applications that include storage, retrieval, application, contribution, and sharing, are effective storage and retrieval mechanisms enabling companies to access knowledge [12].

\section{B. Knowledge Management Enablers}

As knowledge is the most important input factor for maintaining competitive advantage, companies need to consider the knowledge management element (KM) of Enablers as the basis for achieving operational performance. KM Enablers is defined as a corporate mechanism that consciously and consistently applies to the development of knowledge within the company [14]. Therefore, KM Enablers is related to strategy and leadership, corporate culture, people and information technology [7]. Previous research on KM Enablers used different factors, but Information Technology (IT) was generally included as one of them since IT connects company members and knowledge within the company [15].

This study uses transformational leadership, centralized organizational structure, human resources, and IT as factors that represent KM Enabler in the company. Transformational leadership behavior can inspire and motivate employees to commit to achieving the company's vision and turn employees into creators or innovators [16]. Meanwhile, transactional leadership is leadership based on group strength (contingent strengthening). Most automotive component industries in Indonesia are controlled by Japanese automotive companies. Thus, the transfer of knowledge from the main company to the automotive component company is needed to meet product qualifications. And, it is more in line with transformational leadership than transactional leadership.

Leadership is always related to organizational structure. Whereas, organizational structure can be defined as formal relations, activity allocation and company member resources [17]. The organizational structure within the company can encourage KM management and is related to formal rules, jobs, functions, and rules that apply in the company, including policies, processes, hierarchical relationships, reward systems, etc. [17]. There are two types of organizational structures, namely centralized and decentralized organizational structures. Centralized organizational structure refers to the level of hierarchy in organizations related to decision making, where companies with a high type of centralization will require employees to follow certain communication channels, making it possible to produce better projections, consistent production and the ability to use limited resources more effective power [18]. On the other hand, there is a type of decentralized 
TABLE 1. RESULT OF MULTIPLE LINEAR REGRESSION

\begin{tabular}{|c|c|c|c|c|c|}
\hline \multicolumn{6}{|c|}{ Coefficients $^{\mathrm{a}}$} \\
\hline \multirow[b]{2}{*}{ Model } & \multicolumn{2}{|c|}{$\begin{array}{c}\text { Unstandardized } \\
\text { Coefficients }\end{array}$} & $\begin{array}{c}\text { Standardize } \\
\text { d } \\
\text { Coefficients }\end{array}$ & \multirow[t]{2}{*}{$\mathrm{t}$} & \multirow[t]{2}{*}{ Sig. } \\
\hline & B & $\begin{array}{l}\text { Std. } \\
\text { Error }\end{array}$ & Beta & & \\
\hline 1 (Constant) & -1.528 & .334 & - & -4.571 & .000 \\
\hline $\mathrm{TL}$ & .441 & .097 & .289 & 4.524 & .000 \\
\hline $\mathrm{HC}$ & .223 & .049 & .263 & 4.522 & .000 \\
\hline COS & .169 & .062 & .172 & 2.728 & .008 \\
\hline IT & .589 & .071 & .507 & 8.343 & .000 \\
\hline
\end{tabular}

The calculation results above explain that all independent variables have a positive relationship with the dependent variable, and IT variable has the highest relationship with the KMP. In contrast, COS variable has the smallest relationship. And from the analysis of the four hypotheses proposed, only the Centralized Organizational Structure variable was not proven to affect the KMP in the automotive component industry in Indonesia.

Furthermore, the calculation results also reveal the coefficient of determination for this study as shown in Table 2. knowledge for use in work [19]. The importance of IT can be explained through its ability to support communication, collaboration, knowledge exploration and learning [19].

H1: Transformational leadership is positively correlated with KM Process.

H2: Human capital is positively correlated with KM Process.

H3: Centralized Organizational Structure is positively correlated with KM Process.

H4: Information Technology is positively correlated with KM Process.

\section{Methodology}

The type of research used in this study is quantitative methods. The data used in this study are primary data and secondary data. The population of this research is companies that belong to the automotive component industry group in Indonesia. Questionnaires were distributed to operational managers or production managers of these companies. Then, data was collected from 85 operational managers as respondents and representatives of their respective companies.

\section{RESULTS}

This study uses Multiple Regression as the statistical tool, in which Transformational Leadership, Centralized Organizational Structure, Human Capital, and IT are determined as the independent variables and Knowledge Management Process as the dependent variable. This analysis was conducted to find out the direct and indirect relationships of each independent variable with the dependent variable. Based on multiple regression, it was found that the relationship of each independent variable to the dependent variable is illustrated by Table 1 .
TABLE 2. COEFFICIENT DETERMINATION

Table 2 explains in general that transformational leadership, human capital, centralized organizational structure, and IT variables which are factors of Knowledge Management Enabler contribute to KMP as high as 0.779 or $77.9 \%$. While the remaining $22.1 \%$ is influenced by other factors not included in this study.

\section{DISCUSSION}

Based on the calculation results, it was revealed that transformational leadership, human capital, centralized organizational structure and IT correlate with the KMP in the automotive component industry in Indonesia. However, centralized organizational structure was found to have the weakest relationship indicating that organizational structure is not an important factor in the KMP. Therefore, it can be said that KMP is not influenced by centralized organizational structure in this study. On the other hand, IT has the strongest relationship with KMP. It is in accordance with that IT can be a tool that connects employees in one division or between different divisions, so that the process of exchanging information and experience can occur easily.

As for the other two factors, transformational leadership was found to be the second most important factor after IT. It shows that, in this study, transformational leadership makes the process of transferring knowledge and information more facilitated. Specifically, respondents agreed that through

\begin{tabular}{|c|c|c|c|c|}
\hline \multicolumn{5}{|c|}{ Model Summary } \\
\hline Model & $\mathbf{R}$ & R Square & $\begin{array}{l}\text { Adjusted } \\
\text { R Square }\end{array}$ & $\begin{array}{l}\text { Std. Error of the } \\
\text { Estimate }\end{array}$ \\
\hline 1 & $.883^{\mathrm{a}}$ & .779 & .768 & .36010 \\
\hline
\end{tabular}


management process on the creation of innovations: case study,' European Conference on Knowledge Management, 2015, pp. 321 329.

[7] C. L. Chang, and T. C. Lin, "The role of organizational culture in the knowledge management process," Journal of Knowledge Management, 2015.

[8] H. Hussinki, P. Ritala, M. Vanhala, and A. Kianto, "Intellectual capital, knowledge management practices and firm performance," Journal of Intellectual Capital, 2017.

[9] R. Magnier-Watanabe, C. Benton, and D. Senoo, "A study of knowledge management enablers across countries," Knowledge Management Research \& Practice, vol. 9.1, 2011, pp. 17-28.

[10] M. G. Aboelmaged, "Linking operations performance to knowledge management capability: the mediating role of innovation performance," Production Planning \& Control, vol. 25.1, 2014, pp. 44-58.

[11] W. Zhang, and W. Zhang, "Knowledge creation through industry chain in resource-based industry: case study on phosphorus chemical industry chain in western Guizhou of China," Journal of Knowledge Management, 2018.

[12] G. Martín-de Castro, P. López-Sáez, M. Delgado-Verde, T. Andreeva, and A. Kianto, "Knowledge processes, knowledge-intensity and innovation: a moderated mediation analysis," Journal of Knowledge Management, 2011.

[13] R. V. D. Gonzalez, and M. F. Martins, "Knowledge Management Process: a theoretical-conceptual research," Gestão \& Produção, vol. 24.2, 2017, pp. 248-265.

[14] H. Aulawi, I. Sudirman, K. Suryadi, and R. Govindaraju, "Literature review towards knowledge enablers which is assumed significantly influences ks behavior," Journal of Applied Sciences Research, vol. 5.12, 2009, pp. 2262-2270.

[15] C. T. Ho, "The relationship between knowledge management enablers and performance," Industrial Management \& Data Systems, 2009.

[1] Menperin: Industri Komponen jadi Kekuatan Industri Kendaraan Bermotor Nasional, metrotvnews.com, 2016. Accessed on April 26, 2018.

[2] Mimpi Berdikari Otomotif Dalam Negeri, Kesempatan Kedua bagi Industri Otomotif Indonesia, validnews.id, 2018. Accessed on December 10, 2018.

[3] W. Yangpisanphob, Thailand Industry Outlook 2017 - 19, Auto Parts Industry, Krungsri Research.

[4] R. Nurcahyo, and A. D. Wibowo, "Manufacturing capability, manufacturing strategy and performance of Indonesia automotive component manufacturer," Procedia CIRP, vol. 26, 2015, pp. 653657.

[5] K. Y. Wong, L. P. Tan, C. S. Lee, and W. P. Wong, "Knowledge management performance measurement: measures, approaches, trends and future directions," Information Development, vol. 31.3, 2015, pp. 239-257.

[6] I. Girniene, and Z. Atkociuniene, "Impact of knowledge
16] M. Birasnav, "Relationship between transformational leadership behaviors and manufacturing strategy," International Journal of Organizational Analysis, 2014.

[17] C. F. Ho, P. H. Hsieh, and W. H. Hung, "Enablers and processes for effective knowledge management," Industrial Management \& Data Systems, 2014.

[18] P. Garrehy, Centralized vs Decentralized Manufacturing, industrytoday.com, 2014. Accessed on April 14, 2018.

[19] N. Majid, N. Mehran, M. H. Zarei, and S. Somaye, "Critical enablers for knowledge creation process: Synthesizing the literature," 2013, pp. 105-119. 